\title{
Yetişkin Hükümlüler için Topluma Yeniden Uyum Programı'nın Etkililiği
}

\section{Effectiveness of the Community Reintegration Program for Adult Offenders}

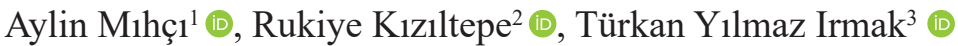

Yazar notu: Bu çalışma, birinci yazarın üçüncü yazar danışmanlığında hazırladığı yüksek lisans bitirme projesinden üretilmiștir.

'Uzman Psikolog, Aydın E Tipi Kapalı Ceza İnfaz Kurumu, Aydın, Türkiye

${ }^{2}$ Araştırma Görevlisi, Ege Üniversitesi, Edebiyat Fakültesi Psikoloji Bölümü, İzmir, Türkiye

${ }^{3}$ Doç. Dr., Ege Üniversitesi, Edebiyat Fakültesi Psikoloji Bölümü, İzmir, Türkiye

ORCID: A.M. 0000-0003-0484-4983; R.K. 0000-0001-8076-3419;

T.Y.I. 0000-0003-0777-7595

Sorumlu yazar/Corresponding author: Türkan Yılmaz Irmak

Ege Üniversitesi, Edebiyat Fakültesi Psikoloji Bölümü, İzmir, Türkiye

E-posta/E-mail:

turkan.yilmaz.irmak@ege.edu.tr

Başvuru/Submitted: 30.09 .2020

Kabul/Accepted: 01.04.2021

Citation/Atıf: Mıhçı, A., Kızıltepe, R. ve Yılmaz Irmak, T. (2021). Yetișkin hükümlüler için Topluma Yeniden Uyum Programı́nın etkililiği. Psikoloji Çalışmaları - Studies in Psychology, 41(2), 735-758. https://doi.org/10.26650/SP2021-802519
ÖZ

Hükümlülerin cezaevinden salıverildikten sonra topluma uyum sağlama konusunda birçok problem yaşadıkları bilinmektedir. Alan yazınında cezaevinde uygulanan ve hükümlülerin yeniden uyumunu sağlamak için geliştirilmiş birçok program bulunmaktadır. Bu çalışmanın amacı, açık ceza infaz kurumunda bulunan hükümlüler için geliștirilmiș olan Topluma Yeniden Uyum Programı'nın etkililiğini incelemektir. Çalışmaya yaşları 26 ile $44($ Ort. $=36.02, S S=6.24)$ arasında değişen 60 erkek hükümlü katılmıştır. Katılımcılar eğitim $(N=30)$ ve karşılaştırma $(N=30)$ gruplarına atanmışlardır. Eğitim grubu iletişim becerileri, öfke ve stresle baș etme modüllerinden oluşan altı haftalık Topluma Yeniden Uyum Programı'na katılmıştır. Eğitimin etkililiğini değerlendirmek için tüm katılımcılar eğitimden önce ve sonra Sürekli Öfke ve Öfke İfade Tarz Ölçeği, Algılanan Stres Ölçeği, İletişim Becerileri Ölçeği ve Kişisel Bilgi Formunu doldurmuşlardır. Eğitimin etkililiğini sınamak için 2 X 2 tekrarlayan ölçümler için ANOVA ve ANCOVA analizleri yürütülmüștür. Analiz sonuçları, zaman ve grup değişkeninin ortak etkisinin İletişim Becerileri Ölçeği'nin alt ölçekleri (temel beceriler ve kendini ifade etme, iletişime özen gösterme, iletişim kurmaya isteklilik, etkin dinleme ve sözel olmayan iletişim, iletişim ilkelerine uyma) ve Sürekli Öfke ve Öfke İfade Tarz Ölçeği'nin üç alt ölçeği (öfke kontrol, öfke-dışa ve öfke-içe) ölçümleri için istatistiksel olarak anlamlı olduğunu göstermektedir. Programa katılımın, eğitim grubundaki katılımcıların iletişim becerileri ve öfke denetimi üzerinde etkili olduğu görülmüştür. Ancak program sürekli öfke, yetersiz özyeterlik algısı ve stres/rahatsızlık algısı üzerinde etkili bulunmamıştır. Sınırlılıklarına karşın, bu çalışmanın yetişkin hükümlülere yönelik müdahale programları alan yazınına önemli katkıları olacağı düşünülmektedir. Programın stres ve öfke konularında geliştirilmesinin ardından çeşitli kurumlarda etkililiğinin incelenmesi ve izlem ölçümlerinin alınması gerekli görülmektedir.

Anahtar Kelimeler: İletişim becerileri, öfke, stres, bilişsel davranışçı yaklaşım, hükümlü 


\section{ABSTRACT}

Offenders experience a number of problems integrating into society after being released from prison. There are examples of many programs that have been developed and implemented in prisons to ensure the reintegration of offenders. The purpose of this study was to examine the effectiveness of the Community Reintegration Program, which was developed for offenders in an open prison. The participants included 60 male offenders between 26 and 44 years of age $(M=$ $36.02, S D=6.24)$. The participants were either assigned to an education group $(N=30)$ or comparison group $(N=$ 30). To evaluate the effectiveness of the education program, the participants completed the Anger Expression and Trait Anger Scale, Perceived Stress Scale, Communication Skills Scale, and Personal Information Form before and after the intervention. The education group participated in a six-week Community Reintegration Program, which comprised three sessions that included communication skills and coping with stress and anger. A series of 2 X 2 repeated measures ANOVA and ANCOVA analyses were conducted to investigate the program's effectiveness. The findings revealed that the interaction effects between group and time were significant for the scores of the subscales of the Communication Skills Scale, specifically, basic skills and personal/self-expression, caring communication, willingness to communicate, active listening and non-verbal communication, and complying with communication principles as well as the three subscales of the Anger Expression and Trait Anger Scale, namely, anger-in, anger-out, and anger control. In relation to communication skills and anger management, the program was found to be effective among those in the education group. However, with regard to trait anger, insufficient self-efficacy, and perceived stress/distress, the program was ineffective. Despite its limitations, this study contributed significantly to the literature on intervention programs for adult offenders. It is recommended that the effectiveness of the program be explored in various institutions. It is further suggested that anger and stress should be measured after the program is improved

Keywords: Communication skills, anger, stress, cognitive behavioral approach, offender.

\section{EXTENDED ABSTRACT}

Offenders frequently experience several psychological struggles such as anger and ineffective problem-solving skills. Therefore, it is imperative to implement effective intervention programs for offenders in prisons (Alexander, 2000; Hayward, McMurran, \& Sellen, 2008). For a number of years, programs based on the cognitive behavioral approach have been implemented so as to reduce recidivism and increase offenders' social skills. Studies have revealed that these programs are effective in enhancing social skills, problemsolving skills, and anger management as well as preventing recidivism (Hollin, 1999; Lipsey, Chapman, \& Landenberger, 2001). However, only a paucity of research has examined the effectiveness of the programs that have been developed for offenders in Turkey. Accordingly, the purpose of this study was to develop a psychoeducational intervention program for adult offenders and examine its efficacy.

\section{Method}

The participants included 60 male offenders between 26 and 44 years of age $(M=36.02$, $S D=6.24)$ who were due to be released in a year. They were assigned to either an education $(N=30)$ or comparison group $(N=30)$. Ethical permission was obtained from the Ege 
University Scientific Research and Publication Ethics Committee. Furthermore, permission was obtained from the General Director of Prisons and Detention Houses of the Ministry of Justice to implement the program. The participants' offenses included crimes of injury, threatening behavior, and murder. The education group participated in a six-week program, namely, the Community Reintegration Program. The program comprised three modules: anger, stress, and communication skills. They also completed the Perceived Stress Scale, Trait Anger and Anger Expression Scale, Communication Skills Scale, and Information Form.

\section{Results}

A series of 2 (Group: Education vs. Comparison) X 2 (Time: Pre-test vs. Post-test) repeated measures ANOVA and ANCOVA analyses were conducted to examine the effectiveness of the Community Reintegration Program. The findings revealed that the interaction effects of time and group were statistically significant for basic skills and self-expression (Wilk's $\lambda$ $=.834, F(1,58)=11.578, p<.001, \eta^{2}=.17$ ), caring communication (Wilk's $\lambda=.915, F(1,58)=$ $5.394, p<.05, \eta^{2}=.09$ ), willingness to communicate (Wilk's $\lambda=.933, F(1,58)=4.182, p<.05$, $\eta^{2}=.07$ ), active listening and non-verbal communication (Wilk's $\lambda=.868, F(1,58)=8.789, p<$ $.01, \eta 2=.13$ ), and complying with communication principles (Wilk's $\lambda=.828, F(1,58)$. A series of 2 (Group: Education vs. Comparison) X 2 (Time: Pre-test vs. Post-test) repeated analyses showed that the interaction effects of time and group were statistically significant for anger control (Wilk's $\lambda=.815, F(1,58)=13.185, p<.001, \eta^{2}=.19$ ), anger-out (Wilk's $\lambda=.856, F(1$, $58)=9.785, p<.01, \eta^{2}=.14$ ), and anger-in (Wilk's $\left.\lambda=.863, F(1,58)=9.204, p<.01, \eta^{2}=.14\right)$. However, the interaction effect was not statistically significant for perceived stress/distress (Wilk's $\left.\lambda=.992, F(1,58)=.476, p>.05, \eta^{2}=.008\right)$. A series of ANCOVA analyses revealed that there were no significant effects of intervention on trait anger $(F(1,57)=3.028, p>.05)$ and insufficient self-efficacy $(F(1,57)=0.00, p>.05)$, after controlling pre-test measurements.

\section{Discussion}

The results revealed that following the intervention while the participants in the education group expressed anger-in and anger-out less, they conveyed controlled anger more. These findings indicate that the program allowed the education group to express their anger in a healthy manner.

Participation in the program was associated with the scores of basic skills and selfexpression, caring communication, willingness to communicate, active listening and nonverbal communication, and complying with communication principles. The findings concur with those of previous studies that have revealed that participation in intervention programs was associated with communication skills (Hayward et al., 2008). 
Perceived stress/distress and insufficient self-efficacy scores increased in both the education and comparison groups. This may be because imprisonment is a stressful experience (Nurse, Woodcock, \& Ormsby, 2003). However, it is recommended that the duration of the stress module should be increased. Furthermore, it is suggested that the content should be revised and interactive practices such as homework, games, and discussion groups added. The implementation of an intervention program developed for adult offenders may be regarded as a strength of this study because of the limited number of studies in this area in Turkey. Furthermore, the effectiveness of the program was noteworthy in that the participants had committed different crimes. However, the study has several limitations. First, no follow-up measurements were obtained. Second, because the participants were in an open prison, the findings of this study cannot be generalized to other offenders in different types of institutions. Finally, there were no female participants. 
Günümüzde ceza infaz kurumları (CİK), toplumun korunması ve hükümlülerin toplum içinde tekrar suç davranışını sergilemelerini önleyecek biçimde iyileştirilerek topluma yeniden uyumunun gerçekleştirildiği hizmet kurumları olarak görülmektedir. Yeniden uyum süreci ile CİK'lerdeki kişilerin fiziksel ve psikolojik sağlığını koruyarak topluma uyumunu sağlamak hedeflenmektedir (Kifer, Hemmens ve Stohr, 2003; Yak1şır, 2006). Alan yazında yetişkin hükümlülerin topluma yeniden uyumunu sağlamak için CİK’te sıklıkla yaşadıkları öfke, iletişim becerileri gibi birçok sorunu azaltmaya yönelik müdahale programları bulunmaktadır (Lipsey, Landenberger ve Wilson, 2007; Wilson, Gallagher ve MacKenzie, 2000). Ülkemizde Adalet Bakanlığı tarafından yetişkin hükümlüler için hazırlanan ve uygulanan Önce Düşün (Genel Suçlu Davranış Programı), Salıverilme Öncesi Mahkum Gelişim Programı, İntihar ve Kendine Zarar Verme Konusunda Farkındalık Programı, Özel Gözetim ve Denetim Programı, Öfke Kontrolü Programı gibi bazı müdahale programları bulunmaktadır (Adalet Bakanlığı, 2017). Bu programlardan biri olan sigara, alkol ve madde kullanımını önlemeye yönelik geliştirilen Sigara Alkol Madde Bağımlılığı (SAMBA) programının denetimli serbestlik kapsamında olan yetişkinlerde etkililiği gösterilmiştir (Bilici ve ark., 2018; Ögel ve ark., 2016). Ancak diğer programların etkililiğine ilişkin araştırmalara ulaşılamamıştır. Porsuk (2017) tarafından Malatya ilinde gerçekleştirilen çalışmada denetimli serbestlik kurumundaki bireysel ve grup uygulamalarından yararlanan yetişkin hükümlülerin kurumda sürdürülen programları yararlı bulduklarını ifade ettikleri görülmektedir. Dolayısıyla yetişkin hükümlülere yönelik bir program geliştirilmesinin ve etkililiğinin incelenmesinin önemli olduğu düşünülmüştür. Öfke denetimi, iletişim becerileri ve stresle baş etme modüllerinden oluşan “Topluma Yeniden Uyum Programı”nın hükümlülerin hem CİK'te kaldıkları süre boyunca hem de salıverildikten sonra toplum içinde uyum sağlamalarına katkıda bulunması beklenmektedir.

Alan yazında sıklıkla suçun, kanun tarafından yasaklanan ve cezalandırılan davranış; suçlunun ise kanunlarca suç olarak tanımlanan fiilleri işleyen kişi olarak tanımlandığı görülmektedir (Özden, 2015; Polat, 2004). Suç olarak tanımlanan eylemleri gerçekleştirdiği mahkeme kararıyla kesinleşen kişiler ise hükümlü olarak adlandırılmaktadır (Demir, 2015). Suça neden olan faktörlerin pek çok psikolojik ve sosyolojik kuram tarafından açıklandığı görülmektedir. Sosyolojik kuramlar yoksulluk, işsizlik ve firsatların yetersizliği gibi toplumsal; psikolojik kuramlarsa kişilik, zeka ve bilişsel stiller gibi bireysel etmenleri vurgulamaktadır. Sosyolojik ve psikolojik faktörler ve bu fak- 
törlerin etkileşimi sonucu suç davranışı ortaya çıkmaktadır (Aksel, 2012; Canter, 2011). Ayrıca hükümlüler ceza kurumlarında da pek çok kısıtll11k ve zorlukla karşılaşabilmektedir (Rogers, 2011). Gerek suça neden olan güçlük yaşantıları gerekse CİK koşullarında yaşama ve topluma uyum sağlamada karşılaşılabilecek olası güçlükler hükümlülük sürecinde pek çok psikososyal soruna yol açabilmektedir (Çaynak ve Kutlu, 2016; Rogers, 2011). Araştırmacılar CİK’teki hükümlülerde öz kıyım girişimi ve kendine zarar verme (Fazel, Hayes, Bartellas, Clerici ve Trestman, 2016; Hayes, 1989), kişilik bozuklukları (Eher, Rettenberger ve Turner, 2019; Fazel ve Danesh, 2002) ve duygudurum bozuklukları (Pliszka, Sherman, Barrow ve Irick, 2000) gibi psikolojik sorunların s1k görüldüğünü belirtmektedir. Hükümlülerin problem çözme, iletişim becerileri ve stres konularında sorun yaşadıkları belirtilmektedir (Antonowicz ve Ross, 2005; Biggam ve Power, 1999; Bourke ve Van Hasselt, 2001).

Hükümlü kişilerde görülen psikolojik sorunlardan birisinin de öfke olduğu belirtilmektedir (Novaco, Ramm ve Black, 2004). Sürekli öfke yaşayanların daha fazla stres yaşadıkları ve stres yaratan durumlara karşı da şiddet içeren tepkiler verdikleri bilinmektedir (Diong ve ark., 2005). Uzun süreli ve yoğun öfke yaşanması durumunda çatışmalar, uyumsuzluk, çevre ile sağlıklı bir şekilde iletişime geçememe ve sosyal sıkıntıların yaşandığı görülmektedir (Çiftçi ve Tüfekçi, 2017). Özdemir (2009) kasten öldürme suçundan hüküm giyen 100 erkek ile yaptı̆̆g çalışmada öfke ve saldırganlık arasındaki ilişkiyi incelemiş ve sürekli öfke, öfke-içe ve öfke-dışa duygularının bildirimi arttıkça saldırganlık davranışı bildirimlerinin de arttığını bulmuştur.

\section{Hükümlülere Yönelik Müdahale Programları}

Hükümlülerin sergilediği çok sayıda soruna yönelik müdahalelere ihtiyaç olduğuna işaret edilmektedir (Alexander, 2000). Hükümlülerin tekrar suç davranış1 gerçekleştirmesini önlemeye yönelik programlar uzun yıllardır uygulanmaktadır. Son yıllarda pek çok çalışmada bu tür programların etkili olduğu (Hollin, 1999; Lipsey, Chapman ve Landenberger, 2001) ve suç tekrarını azalttığı belirtilmektedir (Allen, MacKenzie ve Hickman, 2001; Mpofu, Athanasou, Rafe ve Belshaw, 2018; Redondo, Sanchez-Meca ve Garrido, 1999). Hollin (1999) programların suçu tümüyle ortadan kaldırmayacağını ancak kurbanlar üzerindeki insani ve ekonomik bedellerin azaltılabileceğini belirtmektedir. Bu programlar çok bileşenli olarak hazırlanmakta ve öfke, iletişim becerileri, sosyal beceriler, empati ve problem çözme gibi konuları içermektedir (Bourke ve Van Hasselt, 2001; Polaschek ve Collie, 2004). Allen ve arkadaşları (2001) ahlaki uzlaşma 
terapisi ve muhakeme ve rehabilitasyon yöntemlerinin yeniden suç eyleminde bulunmayı düşürme konusunda etkili olduğunu belirtmektedir. Ancak alandaki çalışmaların çoğunun Bilişsel Davranışçı Yaklaşım (BDY) temelli olduğu görülmektedir. Landenberger ve Lipsey (2005) BDY müdahalelerinin suç tekrarı konusundaki etkisini değerlendirdikleri meta-analiz çalışmalarında BDY programlarının suç tekrarını azalttığını bulmuşlardır. Programlarda en etkili bilişsel davranışçı unsurların öfke denetimi ve kişilerarası problem çözme olduğu görülmüştür. Ayrıca aynı çalışmada BDY'nin hem çocuk hem de yetişkin hükümlülerde etkili olduğu belirtilmektedir. Özetle, alan yazınında son yıllarda yapılan hem meta-analiz (Henwood, Chou ve Browne, 2015) hem de derleme çalışmaları (Mpofu ve ark., 2018) BDY'nin suç tekrarını önlemede etkili olduğunu göstermektedir.

Alan yazında programların suç tekrarını önleme konusundaki etkisinin ölçülmesinin yanı sıra programların farklı alanlardaki etkisine bakan çalışmalar da yer almaktadır. Örneğin, Hayward, McMurran ve Sellen (2008) yetişkin hükümlülere verilen sosyal problem çözme eğitiminin ardından eğitim grubundaki katılımcıların olumlu yönde değişim gösterdiğini bulmuşlardır. Ünlü-Sağdıç (2019) tarafından da yetişkin hükümlü kadınlarla sosyal problem çözme becerilerinin geliştirilmesine yönelik yapılan müdahale çalışmasının etkili olduğu, eğitimin ardından eğitim alan katılımcıların sosyal problem çözme becerilerinin iyileştiği belirtilmiştir.

Öfke konusunda yapılan çalışmaların sonuçları ise çelişkiler içermektedir. Watt ve Howells (1999) yetişkin erkeklerle yaptıkları çalışmada öfke eğitimi sonrasında öfke ve saldırganlıkta bir azalma olmadığını bulmuşlardır. Bazı araştırmalarda eğitim grubunun öfke bilgisinde (örn., öfkeyi tanıma, adlandırma, ipuçlarını anlama gibi) artış görülürken öfke yaşantısında değişim olmadığı bulunmuştur (Heseltine, Howells ve Day, 2010; Howells ve ark., 2005). Schippers, Märker ve De Fuentes-Merillas (2001), 102 erkek hükümlü ile haftada iki saatlik ve dört hafta süren sosyal beceri eğitiminin ardından eğitim alan hükümlülerin sosyal etkileşim becerilerinin arttığını bulmuşlardır. Görüşlerini ifade etme, tartışma, öfkeyi ifade etme ve sosyal ilişki becerilerinde iyileşme olmuş, ancak düşmanca ve saldırgan davranışlar eğitimden etkilenmemiştir. Öfke konusunda yurtdışında yapılan çalışmalarda çelişkili sonuçlar bulunmakla birlikte Türkiye' de yetişkinlerle yapılan çalışmaların sınırlı olduğu görülmektedir. Öfke denetimine yönelik müdahale programlarının çoğu ergenlere (Duran ve Eldeleklioğlu, 2005; Özbay, 2008; Şekerci, Terzi, Kitiş ve Okuyan, 2017 ; Tekinsav Sütçü, Aydın ve Sorias, 2010) uygulan- 
mıştır ve yetişkinlere yönelik çalışmaların (Bkz. İskit, 2019) azlığı göze çarpmaktadır. Ergenlerle yapılan çalışmalar arasında ise hükümlü ergen katılımcıların yer aldığı çalışmalar oldukça kısıtlıdır (Bkz. Özbay, 2008). Ülkemizde öfke denetimi konusunda yetişkin hükümlülere uygulanarak program etkililiğinin incelendiği bir müdahale çalışmasına ulaşılamamıştır. Günümüzdeki infaz anlayışı kapsamında hükümlü ve tutukluların topluma uyumlu bireyler olmasını sağlamak için Adalet Bakanlığı tarafindan Salıverilme Öncesi Mahkum Gelişimi Programının uygulandığı görülmektedir (Adalet Bakanlığı, 2017). Ancak bu programın etkililik değerlendirmelerine ulaşılamamıştır.

$\mathrm{Bu}$ araştırmanın amacı CİK'lerde bulunan hükümlülerin iletişim becerileri, stres ve öfke konularında yaşadıkları sorunları çözmeleri ve topluma uyumlarını sağlamak için bir psikoeğitim programı hazırlayarak, uygulamak ve bu programın etkililiğini incelemektir. Bu çalışma kapsamında ülkemizde yetişkin hükümlülere yönelik BDY'ye dayanan bir psikoeğitim programı hazırlanmıştır. Program şiddet suçu işleyen hükümlüler için özellikle önem taşıyan ve çeşitli programlar (Ireland, 2004; Polaschek ve Collie, 2004) tarafından da içerilen iletişim becerileri, stresle baş etme ve öfke konularını kapsamaktadır. Bu çalışmanın iletişim becerileri $\left(H_{1}-H_{5}\right)$, stres $\left(H_{6}-H_{7}\right)$ ve öfke $\left(H_{8}-H_{11}\right)$ ile ilişkili hipotezleri aşağıda yer almaktadır:

H1: Eğitim grubundaki hükümlülerin karşılaştırma grubundaki hükümlülere göre temel beceriler ve kendini ifade etme puanları eğitim sonrasında anlamlı olarak artacaktır.

H2: Eğitim grubundaki hükümlülerin karş1laştırma grubundaki hükümlülere göre iletişime özen gösterme puanları eğitim sonrasında anlamlı olarak artacaktır.

H3: Eğitim grubundaki hükümlülerin karşılaştırma grubundaki hükümlülere göre ilişki kurmaya isteklilik puanları eğitim sonrasında anlamlı olarak artacaktır.

H4: Eğitim grubundaki hükümlülerin karşılaştırma grubundaki hükümlülere göre etkin dinleme ve sözel olmayan iletişim puanları eğitim sonrasında anlamlı olarak artacaktır.

H5: Eğitim grubundaki hükümlülerin karşılaştırma grubundaki hükümlülere göre iletişim ilkelerine uyma puanları eğitim sonrasında anlamlı olarak artacaktır.

H6: Eğitim grubundaki hükümlülerin karşılaştırma grubundaki hükümlülere göre stres/rahatsızlık algısı puanları eğitim sonrasında anlamlı olarak azalacaktır. 
H7: Eğitim grubundaki hükümlülerin karşılaştırma grubundaki hükümlülere göre yetersiz özyeterlik algısı puanları eğitim sonrasında anlamlı olarak azalacaktır.

H8: Eğitim grubundaki hükümlülerin karş1laştırma grubundaki hükümlülere göre sürekli öfke puanları eğitim sonrasında anlamlı olarak azalacaktır.

H9: Eğitim grubundaki hükümlülerin karşılaştırma grubundaki hükümlülere göre öfke kontrolü puanları eğitim sonrasında anlamlı olarak artacaktır.

H10: Eğitim grubundaki hükümlülerin karşılaştırma grubundaki hükümlülere göre öfke-içe puanları eğitim sonrasında anlamlı olarak azalacaktır.

H11: Eğitim grubundaki hükümlülerin karşılaştırma grubundaki hükümlülere göre öfke-dışa puanları eğitim sonrasında anlamlı olarak azalacaktır.

\section{YÖNTEM}

\section{Katılımcılar}

Bu çalışmanın örneklemini, Aydın Açık Ceza İnfaz Kurumu'nda salıverilmesine en fazla bir yıl kalan, çeşitli şiddet suçlarından ceza almış 60 erkek hükümlü oluşturmaktadır. Katılımcılar eğitim ve karşılaştırma olmak üzere 30'ar kişilik iki gruba ayrılııştır. Katılımcıların yaşları 26 ile 44 arasında değişmektedir $(O r t .=36.02, S S=6.24)$. Eğitim grubundaki katılımcıların yaş ortalaması $37.40(S S=5.71)$ iken karş1laştırma grubundaki katılımcıların yaş ortalaması 34.63'tür $(S S=6.54)$. Katılımcıların suç bilgileri kurum dosyalarından ilk araştırmacı tarafından elde edilmiştir. Eğitim grubundaki katılımcıların \%33.3'ü $(N=10)$ yaralama, \%16.7'si $(N=5)$ kasten öldürme, \%26.7'si $(N=8)$ tehdit etme ve $\% 23.3$ 'ü $(N=7)$ hakaret nedeniyle hükümlüdür. Karş1laştırma grubundaki katılımcıların ise \%26.7'si $(N=8)$ yaralama, \%20'si $(N=6)$ kasten öldürme, $\% 30$ 'u ( $N$ =9) tehdit etme ve $\% 23.3$ 'ü $(N=7)$ hakaret nedeniyle hükümlüdür. Katılımc1lara ait demografik özelliklerin dağılımı Tablo 1'de gösterilmektedir. 
Tablo 1. Katılımcılara Ait Sosyodemografik Özelliklerin Dağılımı

\begin{tabular}{lcccc}
\hline & \multicolumn{2}{c}{ Eğitim Grubu } & \multicolumn{2}{c}{ Karşılaştırma Grubu } \\
\cline { 2 - 5 } & $N$ & $\%$ & $N$ & $\%$ \\
\cline { 2 - 5 } Eğitim Düzeyi* & & & & \\
İlkokul & 20 & 66.7 & 6 & 26.7 \\
Ortaokul & 5 & 16.7 & 16 & 20 \\
Lise & 5 & 16.7 & & 53.3 \\
Meslek & & & 9 & 30 \\
İşsiz & 10 & 33.3 & 10 & 33.3 \\
Serbest meslek & 11 & 36.7 & 6 & 20 \\
İşçi & 5 & 16.7 & 5 & 16.7 \\
Diğer & 4 & 13.3 & 13 & 43.3 \\
Medeni Durum & & & 12 & 40 \\
Evli & 20 & 66.7 & 5 & 16.7 \\
Bekar & 6 & 20 & & 26.7 \\
Boşanmış & 4 & 13.3 & 8 & 20 \\
Suç Türü & & & 6 & 23.3 \\
Yaralama & 10 & 33.3 & 9 & 7 \\
Kasten öldürme & 5 & 16.7 & 76.7 & \\
Tehdit & 8 & 23.3 & & \\
Hakaret & 7 & &
\end{tabular}

*Eğitim ve karşılaştırma grubu eğitim düzeyi bakımından anlamlı bir farklılaşma olduğunu göstermektedir.

Tablo 1'de görüldüğü üzere eğitim ve karşılaştırma grubu, eğitim düzeyi dışında, diğer demografik özellikler bakımından benzerlik göstermektedir. Eğitim grubundaki katılımcıların yarısından fazlasının ilkokul mezunu olduğu, karşılaştırma grubundaki katılımcıların ise yarısından fazlasının lise mezunu olduğu görülmektedir.

\section{Veri Toplama Araçları}

İletişim Becerileri Ölçeği-Yetişkin Formu. Korkut-Owen ve Bugay (2014) tarafindan üniversite öğrencileri için geliştirilen İletişim Becerileri Ölçeği'nin yetişkin örneklem için geçerlik güvenirlik çalışması Korkut-Owen ve Demirbaş-Çelik (2018) tarafından yapılmıştır. Ölçek iletişim becerilerini 5'li likert tipinde (1 = Hiçbir zaman, 5 = Her zaman) 25 madde ile değerlendirmektedir. Ölçeğin temel beceriler ve kendini ifade etme, iletişime özen gösterme, etkin dinleme ve sözel olmayan iletişim, ilişki kurmaya isteklilik ve iletişim ilkelerine uyma olmak üzere beş alt boyutu bulunmaktadır. Korkut-Owen ve Demirbaş-Çelik (2018) tarafından yürütülen çalışmada ölçeğin alt ölçeklerinin Cronbach alfa iç tutarlılık katsayıları sırasıyla .95, .81, .74, .76 ve .65 olarak bulunmuştur. Bu çalışmadaki ön test ve son test uygulamaları için Cronbach alfa iç tutarlılık katsayıları sırasıyla .90/.95, .81/.93, .70/.89, .83/.92 ve .58/.90 olarak bulunmuştur. 
Algılanan Stres Ölçeği. Kişinin hayatındaki durumları stresli algılama düzeyini değerlendiren bu ölçek Cohen, Kamarck ve Mermelstein (1983) tarafından geliştirilmiş ve Eskin, Harlak, Demirkıran ve Dereboy (2013) tarafından Türkçeye uyarlanmıştır. Ölçeğin 14, 10 ve 4 maddelik formları bulunmaktadır ve bu çalışmada 10 maddelik formu kullanılmıştır. Ölçek maddeleri 5'li likert tipinde ( 0 = Hiçbir zaman, 4 = Çok sık) derecelendirilmektedir. Ölçeğin stres/rahatsızlık algısı ve yetersiz özyeterlik algısı olmak üzere iki alt boyutu bulunmaktadır. Ölçeğin 10 maddelik formunun Cronbach değeri tüm ölçek için .82, stres/rahatsızlık algısı alt ölçeği için .80 ve yetersiz özyeterlik algısı alt ölçeği için .69 olarak bulunmuştur (Eskin ve ark., 2013). Bu çalışmada stres/rahatsızl1k algısı alt ölçeğinin Cronbach alfa iç tutarlılık katsayısı ön test için .70, son test için .50 olarak bulunmuştur. Yetersiz özyeterlik algısı ölçeğinin ön test ve son test için Cronbach alfa iç tutarlılık katsayıları sırasıyla .51 ve $.77^{\prime}$ dir.

Sürekli Öfke ve Öfke İfade Tarzı Ölçeği. Spielberger, Jacobs, Russell ve Crane (1983) tarafından geliştirilen ölçek öfke duygusunun sıklığı, yoğunluğu ve kontrolünü ölçmek amacıyla geliştirilmiştir. Ölçek Türkçeye Özer (1994) tarafından uyarlanmıştır. Katılımcılar her maddeyi 4'lü likert tipinde (1 = Hiç değil, 4 = Tamamen) değerlendirmektedir Dört alt boyuttan oluşan ölçekte 34 madde yer almaktadır. Sürekli öfke, öfkenin yaşanma sıklığını; öfke-içe, öfkenin bastırılarak içte tutulmasını; öfke-dışa, öfkenin dışa vurulmasını ve öfke kontrol, öfkenin kontrol edilmesini değerlendirmektedir. Ölçeğin farklı örneklemlerde Cronbach alfa iç tutarlılık değerlerinin sürekli öfke için .67 ile .92 arasında; öfke-kontrol boyutu için .80 ile .90; öfke-dışa boyutu için .69 ile .91 ve öfke-içe boyutu için .58 ile .76 arasında olduğu bulunmuştur (Özer, 1994). Bu çalışmada Cronbach alfa iç tutarlılık katsayıları (ön test/son test) sürekli öfke için .89/.85, öfke kontrolü için .89/.91, öfke dişa için .85/.89 ve öfke içe için .60/.74 olarak bulunmuştur.

Kişisel Bilgi Formu. Araştırmacılar tarafından hükümlülerin yaşı, ceza geçmişleri, eğitim durumları gibi sosyo-demografik bilgileri öğrenmek amacıyla geliştirilmiştir.

Eğitim İçeriği. Eğitim içeriği, suçla ilişkili risk faktörleri ve hükümlülere yönelik bilişsel davranışçı yaklaşıma sahip müdahale çalışmaları (örn., Sütçü ve ark., 2010) alan yazını taranarak üç modül olacak şekilde oluşturulmuştur. Ayrıca eğitim programının oluşturulma sürecinde Adalet Bakanlığg tarafindan uygulanan programlar (Salıverilme Öncesi Mahkum Gelişim Programı ve Öfke Kontrolü Programı vb.) da yol gösterici olmuştur (Adalet Bakanlığı, 2017). İletişim ve iletişim becerileri modülünde iletişimin 
temel ilkeleri, sözel ve sözel olmayan iletişimin (yüz ifadesi, beden duruşu gibi) özelliklerini tanıma, iletişimi başlatma, iletişim sorunlarını belirleme ve çözme konularına yer verilmiştir. Stresle baş etme modülünde stresin fizyolojik ve duygusal belirtilerini tanıma, stres yaratan durumları fark etme ve sağlıklı bir biçimde baş edebilme konuları işlenmiştir. Katılımcıların stresle baş etme becerilerine yardımcı olmak amacıyla nefes egzersizi uygulamaları da yürütülmüştür. Öfke ve öfke denetimi modülünde ise öfkenin fizyolojik ve duygusal belirtilerini tanıma ve öfkeyi sağlıklı bir biçimde ifade etme konularına yer verilmiştir. Programda kuramsal bilginin yanı sıra canlandırma, tartışma, videolar gibi etkileşim içeren etkinlikler de kullanılmıştır.

\section{İşlem}

Araştırma için Ege Üniversitesi Bilimsel Araştırma ve Yayın Etiği Kurulu'ndan 28.03.2019 tarih ve 04/17 karar say1lı (Protokol Numarası: 211) etik kurul onayı alınmıştır. T.C Adalet Bakanlığg Ceza ve Tevkifevleri Genel Müdürlüğü’nden ise CİK’te uygulama yapabilmek için izin alınmıştır. Bir açık ceza infaz kurumunda yaralama, tehdit, hakaret ve kasten öldürme nedeniyle bulunan ve salıverilmesine bir yıl kalan hükümlülerle Mayıs-Haziran 2019 döneminde çalışılmıştır. Uygulamalara gönüllü olan 60 yetişkin erkek hükümlü katılmıştır. Eğitim uygulamalarına katılımın devamlılığını sağlamak için hükümlülerin iş programları dikkate alınarak eğitim ve karşılaştırma grupları oluşturulmuştur. Katılımcılardan yazılı olarak bilgilendirilmiş onamları alınmıştır.

Bu çalışma kapsamında hükümlüler altı hafta boyunca, haftada iki saat süren eğitim programı uygulamalarına katılmışlardır. Her modülün uygulanması iki haftada tamamlanmıştır. Eğitim uygulamaları ilk yazar tarafından kurumun bünyesindeki dersliklerde gerçekleştirilmiştir. Uygulamalar 15'er kişilik iki grupta yürütülmüştür. Eğitim ve karş1laştırma gruplarına eş zamanlı olarak eğitimden bir hafta önce ön test ve eğitimden bir hafta sonra ise son test uygulanmıştır. Son test ölçümleri alındıktan sonra eğitim programı karşılaştırma grubuna da uygulanmıştır.

\section{Veri Analizi}

Verileri analiz etmek için SPSS Paket Programı 20 kullanılmıştır. Yapılan betimleyici analizlerde kayıp verilerin en fazla temel beceriler ve kendini ifade etme alt ölçeğinde (\%6.7) olduğu görülmüştür. En az kayıp veri ise iletişime özen gösterme (\%1.7), etkin dinleme ve sözel olmayan iletişim (\%1.7), öfke-kontrol (\%1.7) ve öfke-dişa (\%1.7) alt ölçeklerindedir. Veri setinde bulunan kayıp verilerin dağılımının rastgele olup olmadığı- 
nı incelemek için Little's MCAR analizi yapılmış ve veri setinde bulunan kayıp verilerin rastgele dağıldığ 1 gözlenmiştir (Chi-Square $=0.00, d f=791, p>.05$ ). Ölçeklerden elde edilen puanların basıklık çarpıklık değerleri incelendiğinde verinin normal olarak dağıldığı saptanmıştır. Veri setindeki kayıp veriler yerine ortalama atama yöntemi kullanılmıştır.

Eğitim ve karşılaştırma grubunun demografik değişkenler bakımından birbirine denk olup olmadığını incelemek için ki kare ve $t$-testi yürütülmüştür. Programın etkililiğini incelemek amaciyla tekrarlayan ölçümler için ANOVA ve ANCOVA analizleri gerçekleştirilmiştir. ANOVA analizlerinde ortak etkiler Kontrast yöntemi ve Bonferroni düzeltmesi ile incelenmiştir. Yetersiz özyeterlik algısı ve sürekli öfke alt ölçek ön test puanları eğitim ve karşılaştırma grupları arasında farklılaştığından bu alt ölçekler için ANCOVA analizi yürütülmüştür. Ayrıca eğitim ve karşılaştırma grupları eğitim düzeyi bakımından birbirinden farklılaşmasına rağmen, bu değişken katılımcıların ön test puanı üzerinde anlamlı bir etkiye sahip olmadığından kovaryans olarak analizlere dahil edilmemiştir.

\section{BULGULAR}

Topluma Yeniden Uyum Programı'nın etkililiği 2 (Grup: Eğitim ve Karşılaştırma) X 2 (Zaman: Ön test ve Son test) tekrarlayan ölçümler için ANOVA ve ANCOVA analizleri ile incelenmiştir. Eğitim ve karşılaştırma gruplarının ön test-son test ölçümlerine ilişkin betimsel değerler Tablo 2'de sunulmaktadır.

$H 1$ 'i test etmek için temel beceriler ve kendini ifade etme puanlarına 2 X 2 tekrarlayan ölçümler için ANOVA analizi uygulanmıştır. Analiz sonucunda zaman ve grup değişkenlerinin ana etkilerinin istatistiksel olarak anlamlı olmadığı görülmüştür (sırasıyla Wilk's $\left.\lambda=1.00, F(1,58)=.029, p>.05, \eta^{2}=.00 ; F(1,58)=1.272, p>.05, \eta^{2}=.02\right)$. Zaman ve grup değişkenlerinin ortak etkisinin ise anlamlı olduğu bulunmuştur (Wilk's $\left.\lambda=.834, F(1,58)=11.578, p<.001, \eta^{2}=.17\right)$. Farkın kaynağını belirlemek için yürütülen ikili karşılaştırmalarda eğitim (Ort. $=33.22, S S=8.15)$ ve karşılaştırma gruplarının $($ Ort. $=35.97, S S=9.13)$ ön test puanları benzerken, son test puanları $\left(\right.$ Ort $t_{\text {eğtim }}=37.57$, $S S=3.13 ;$ Ort $\left.t_{\text {karşılaşırıma }}=31.17, S S=10.31\right)$ arasında anlamlı bir farklılaşma olduğu saptanmıştır. Ayrıca eğitim grubunun puanları ön testten son teste istatistiksel olarak anlam11 biçimde artarken, karşılaştırma grubunun puanları anlamlı biçimde azalmaktadır. Diğer bir deyişle, eğitim grubunun temel beceriler ve kendini ifade etme becerileri eği- 
tim sonunda artarken, karşılaştırma grubunun becerileri azalmıştır. Bu bulgu H1'in desteklendiğini göstermektedir.

Tablo 2. Eğitim ve Karşılaştırma Gruplarının Ön Test ve Son Test Ölçümlerinin Ortalama ve Standart Sapma Değerleri

\begin{tabular}{|c|c|c|c|c|}
\hline & \multicolumn{2}{|c|}{ Ön test } & \multicolumn{2}{|c|}{ Son test } \\
\hline & Ort. & SS & Ort. & SS \\
\hline \multicolumn{5}{|c|}{ Temel Beceriler-Kendini İfade Etme } \\
\hline Eğitim Grubu & 33.22 & 8.15 & 37.57 & 3.13 \\
\hline Karşılaştırma Grubu & 35.97 & 9.13 & 31.17 & 10.31 \\
\hline \multicolumn{5}{|l|}{ İletişime Özen Gösterme } \\
\hline Ĕ̆itim Grubu & 10.98 & 2.91 & 11.80 & 1.56 \\
\hline Karşılaştırma Grubu & 11.77 & 3.14 & 9.20 & 3.62 \\
\hline \multicolumn{5}{|l|}{ İlişki Kurmaya İsteklilik } \\
\hline Eğitim Grubu & 11.52 & 2.69 & 11.40 & 1.22 \\
\hline Karşılaştırma Grubu & 11.60 & 3.43 & 9.47 & 3.98 \\
\hline \multicolumn{5}{|c|}{ Etkin Dinleme ve Sözel Olmayan İletişim } \\
\hline Eğitim Grubu & 19.09 & 4.47 & 21.20 & 1.97 \\
\hline Karşılaştırma Grubu & 20.10 & 5.45 & 17.47 & 6.11 \\
\hline \multicolumn{5}{|l|}{ İletişim İlkelerine Uyma } \\
\hline Eğitim Grubu & 10.98 & 2.92 & 11.80 & 1.56 \\
\hline Karşılaştırma Grubu & 11.77 & 3.14 & 9.20 & 3.62 \\
\hline \multicolumn{5}{|l|}{ Stres/Rahatsızlık Algis1 } \\
\hline Eğitim Grubu & 17.07 & 3.96 & 19.43 & 2.22 \\
\hline Karşılaştırma Grubu & 16.33 & 4.62 & 18.07 & 2.45 \\
\hline \multicolumn{5}{|l|}{ Yetersiz Özyeterlik Algisı } \\
\hline Eğitim Grubu & 11.93 & 3.19 & 12.07 & 1.11 \\
\hline Karşılaştırma Grubu & 10.43 & 2.40 & 12 & 1.49 \\
\hline \multicolumn{5}{|l|}{ Sürekli Öfke } \\
\hline Eğitim Grubu & 21.33 & 7.55 & 19.23 & 5.16 \\
\hline Karş1laştırma Grubu & 16.77 & 4.23 & 18.07 & 4.44 \\
\hline \multicolumn{5}{|l|}{ Öfke Kontrolü } \\
\hline Eğitim Grubu & 22.15 & 5.86 & 24.90 & 3.57 \\
\hline Karşılaştırma Grubu & 22.17 & 4.84 & 20.67 & 4.29 \\
\hline \multicolumn{5}{|l|}{ Öfke-içe } \\
\hline Eğitim Grubu & 16.50 & 4.45 & 15.40 & 3.77 \\
\hline Karşılaştırma Grubu & 15.33 & 3.58 & 16.17 & 4.04 \\
\hline \multicolumn{5}{|l|}{ Öfke-dışa } \\
\hline Eğitim Grubu & 15.90 & 5.46 & 14.40 & 4.52 \\
\hline Karşılaştırma Grubu & 14.07 & 4.98 & 15.27 & 5.25 \\
\hline
\end{tabular}

H2'yi test etmek için iletişime özen gösterme puanlarına 2 X 2 tekrarlayan ölçümler için ANOVA analizi uygulanmıştır. Zamanın ana etkisinin istatistiksel olarak anlamsız olduğu görülmüştür (Wilk's $\lambda=.971, F(1,58)=1.742, p>.05, \eta^{2}=.03$ ). Grup değişkeninin ana etkisinin $\left(F(1,58)=4.620, p<.05, \eta^{2}=.074\right)$ ve grup ve zaman değişkenleri- 
nin ortak etkisinin istatistiksel olarak anlamlı olduğu bulunmuştur (Wilk's $\lambda=.915, F(1$, $\left.58)=5.394, p<.05, \eta^{2}=.09\right)$. İkili karşılaştırmalarda eğitim $($ Ort. $=10.98, S S=2.91)$ ve karşılaştırma gruplarının $($ Ort. $=11.77, S S=3.14)$ ön test puanlarının benzer olduğu, son test puanlarının $\left(O r t_{\text {eğitim }}=11.80, S S=1.56\right.$; $\left.O r t_{\text {karşlaş̧ırma }}=9.20, S S=3.62\right)$ ise istatistiksel olarak anlamlı biçimde farklılaştı̆̆ 1 görülmüştür. Ayrıca ön testten son teste eğitim grubunun puanları farklılaşmazken, karşılaştırma grubunun puanlarının düştüğü gözlenmiştir. Diğer bir deyişle, eğitimin ardından eğitim grubunun iletişime özen gösterme puanları değişmezken karşılaştırma grubundaki katılımcıların puanları düşmektedir.

H3 'ü test etmek için ilişki kurmaya isteklilik puanları 2 X 2 tekrarlayan ölçümler için ANOVA analiziyle incelenmiştir. Zaman değişkeninin ana etkisinin istatistiksel olarak anlamlı olduğu (Wilk's $\lambda=.917, F(1,58)=5.225, p<.05, \eta^{2}=.083$ ), grup değişkeninin ana etkisinin anlamlı olmadığ 1 bulunmuştur, $F(1,58)=2.365, p>.05, \eta^{2}=.039$. Grup ve zaman değişkenlerinin ortak etkisinin anlamlı olduğu görülmüştür (Wilk’s $\lambda=$ 933, $\left.F(1,58)=4.182, p<.05, \eta^{2}=.07\right)$. İkili karşılaştırmalarda eğitim (Ort. $=11.52, S S$ $=2.69)$ ve karşılaştırma (Ort. $=11.60, S S=3.43)$ gruplarının puanları ön testte farklılaşmazken, son testte $\left(O r t_{\text {eğtim }}{ }^{\circ}=11.40, S S=1.22 ;\right.$ Ort $\left._{\text {karșılaștırma. }}{ }^{\circ}=9.47, S S=3.98\right)$ anlaml bir biçimde farklılaşmaktadır. Ayrıca ön testten son testte eğitim grubunun puanı değişmezken, karşılaştırma grubunun puanı anlamlı bir biçimde azalmaktadır. Diğer bir deyişle, Topluma Yeniden Uyum Programı eğitim grubunun iletişim kurmaya isteklilik puanlarının düşüşüne engel olmaktadır.

H4'ü test etmek için etkin dinleme ve sözel olmayan iletişim puanları 2 X 2 tekrarlayan ölçümler için ANOVA analizi ile incelenmiştir. Analiz sonucunda etkin dinleme ve sözel olmayan iletişim için zamanın ve grup değişkeninin ana etkilerinin istatistiksel açıdan anlamlı olmadığ görülmüştür (sırasılla Wilk's $\lambda=.998, F(1,58)=.105, p>.05$, $\left.\eta^{2}=.002 ; F(1,58)=2.114, p>.05, \eta^{2}=.04\right)$. Zaman ve grup değişkenlerinin ortak etkisinin ise anlamlı olduğu bulunmuştur (Wilk's $\lambda=.868, F(1,58)=8.789, p<.01, \eta^{2}=$ .13). Farkın kaynağını belirlemek için yürütülen ikili karşılaştırmalarda eğitim (Ort. $=$ 19.09, $S S=4.47)$ ve karşılaştırma grupları (Ort. $=20.10, S S=5.45)$ arasında ön test puanları için anlamlı bir farklılaşma bulunmazken, son testte puanların (Ort $t_{\text {eğitim }}=$ 21.20, $S S=1.97$; $O r t_{\text {karşlaş̧trma }}=17.47, S S=6.11$ ) farklılaştığ ${ }_{1}$ görülmüştür. Ayrıca ön testten son teste eğitim grubunun puanları marjinal bir biçimde artarken, karşılaştırma grubunun puanının anlamlı bir biçimde azaldığı bulunmuştur. Bu bulgu H4'ün desteklendiğini göstermektedir. 
H5'i test etmek için iletişim ilkelerine uyma puanları 2 X 2 tekrarlayan ölçümler için ANOVA analizi ile değerlendirilmiştir. Yapılan analizde zaman ve grup değişkenlerinin ana etkilerinin istatistiksel açıdan anlamsız olduğu görülmüştür (sırasıyla Wilk's $\lambda=$ $\left..945, F(1,58)=3.201, p>.05, \eta^{2}=.05 ; F(1,58)=2.507, p>.05, \eta^{2}=.041\right)$. Zaman ve grup değişkeninin ortak etkisinin ise anlamlı olduğu bulunmuştur (Wilk's $\lambda=.828, F(1$, $\left.58)=12.054, p<.001, \eta^{2}=.17\right)$. Yapılan ikili karşılaştırmalarda eğitim (Ort. $=10.98$, $S S=2.92)$ ve karşılaştırma gruplarının $($ Ort. $=11.77, S S=3.14)$ puanları arasında ön testte anlamlı bir farklılaşma bulunmazken, son testte eğitim (Ort. $=11.80, S S=1.56)$ ve karşılaştırma grubunun $($ Ort. $=9.20, S S=3.62)$ puanlarının farklılaştığı görülmüştür. Ayrıca ön testten son teste eğitim grubunun puanları farklılaşmazken, karşılaştırma grubunun puanlarının anlamlı bir biçimde azalmaktadır.

H6,yı test etmek için stres/rahatsızlık algısı puanları 2 X 2 tekrarlayan ölçümler için ANOVA analiziyle değerlendirilmiştir. Zamanın ana etkisi istatistiksel olarak anlamlı iken (Wilk's $\lambda=.744, F(1,58)=19.956, p<.001, \eta^{2}=.26$ ), grup değişkeninin ana etkisinin anlamlı olmadığ bulunmuştur $\left(F(1,58)=1.875, p>.05, \eta^{2}=.031\right)$. Grup ve zamanın ortak etkisinin de istatistiksel olarak anlamsız olduğu görülmüştür (Wilk's $\lambda=$ .992, $\left.F(1,58)=.476, p>.05, \eta^{2}=.008\right)$. Bu bulgu H6'nın desteklenmediğini göstermektedir.

Grupların yetersiz özyeterlik algısı ön test puanları farklılaştığı için $H 7^{\prime}$ 'yi test etmek amacıyla ön test puanları kovaryans olarak analize dahil edilmiş ve iki grubun son test puanları ANCOVA ile karşılaştırılmıştır. Analiz sonucunda ön test puanlarının son test puanları üzerindeki kovaryans etkisinin anlamlı olmadığı bulunmuştur $(F(1,57)=.610$, $p>$.05). Analiz sonunda eğitim ve karşılaştırma gruplarının son test yetersiz özyeterlik algısı puanlarının farklılaşmadığı saptanmıştır $(F(1,57)=0.00, p>.05)$. Bu bulgu H7’nin desteklenmediğine işaret etmektedir.

H8'i test etmek için farklılaşan ön test sürekli öfke puanları kovaryans olarak analize dahil edilmiş ve eğitim ve karşılaştırma gruplarının sürekli öfke son test puanları ile ANCOVA yürütülmüştür. Yapılan analizde sürekli öfke ön test puanlarının kovaryans etkisinin istatistiksel olarak anlamlı biçimde son test puanları üzerinde etkili olduğu bulunmuştur $(F(1,57)=74.481, p<.001)$. Ön test puanları kontrol edildikten sonra eğitim ve karşılaştırma gruplarının son test sürekli öfke puanlarının farklılaşmadığı saptanmış$\operatorname{tır}(F(1,57)=3.028, p>.05)$. Bu bulgu $H 8^{\prime}$ in desteklenmediğine işaret etmektedir. 
H9'u test etmek için öfke kontrol puanlarına uygulanan 2 X 2 tekrarlayan ölçümler için ANOVA analizi sonucunda zamanın ana etkisinin istatistiksel olarak anlamsız olduğu bulunmuştur (Wilk's $\lambda=.981, F(1,58)=1.140, p>.05, \eta^{2}=.02$ ). Grup değişkeninin ana etkisi ise marjinal olarak anlamlıdır $\left(F(1,58)=3.900, p=.053, \eta^{2}=.063\right)$. Grup ve zaman değişkenlerinin ortak etkisinin anlamlı olduğu bulunmuştur (Wilk's $\lambda=.815$, $\left.F(1,58)=13.185, p<.001, \eta^{2}=.19\right)$. İkili karşılaştırmalarda eğitim $($ Ort. $=22.15, S S=$ 5.86) ve karş1laştırma gruplarının $(O r t .=22.17, S S=4.84)$ ön test puanlarının istatistiksel olarak anlamlı bir biçimde farklılaşmadığı, ancak son test puanlarının (Ort $t_{\text {eğitim }}=$ 24.90, $S S=3.57$; Ort karșılaștırma $=20.67, S S=4.29$ ) anlamlı biçimde farklılaştığı saptanmıştır. Ayrıca ön testten son teste eğitim grubunun öfke kontrol puanları artarken, karşılaştırma grubunun puanları değişmemiştir. Diğer bir deyişle, karşılaştırma grubuna göre eğitim grubu öfkelerini daha fazla kontrol etmeye başlamıştır ve bu bulgu H9'un desteklendiğini göstermektedir.

H10'u test etmek için öfke-içe puanlarına 2 X 2 tekrarlayan ölçümler için ANOVA uygulanmıştır. Zaman (Wilk's $\left.\lambda=.997, F(1,58)=.175, p>.05, \eta^{2}=.003\right)$ ve grup $(F(1$, $\left.58)=.042, p>.05, \eta^{2}=.001\right)$ değişkenlerinin ana etkilerinin istatistiksel olarak anlamsız olduğu bulunmuştur. Grup ve zaman değişkenlerinin ortak etkisinin istatistiksel olarak anlamlı olduğu görülmüştür (Wilk's $\lambda=.863, F(1,58)=9.204, p<.01, \eta^{2}=.14$ ). İkili karş1laştırmalarda ön testten $($ Ort. $=16.50, S S=4.45)$ son teste $($ Ort. $=15.40, S S=$ 3.77) eğitim grubunun puanları anlamlı bir biçimde azalırken, karşılaştırma grubunun ön test $($ Ort. $=15.33, S S=3.58)$ ve son test puanlarının $(O r t .=16.17, S S=4.04)$ farkl1laşmadığ1 görülmüştür. Diğer bir deyişle, karşılaştırma grubuna göre eğitim grubunun öfke-içe puanları eğitim sonunda azalmıştır. Bu bulgu H10'nun desteklendiğini göstermektedir.

H11'i test etmek amacıyla öfke-dışa puanları için 2 X 2 tekrarlayan ölçümler için ANOVA analizi yürütülmüştür. Zaman (Wilk's $\lambda=.998, F(1,58)=.121, p>.05, \eta^{2}=$ $.002)$ ve grup $\left(F(1,58)=.154, p>.05, \eta^{2}=.003\right)$ değişkenlerinin ana etkilerinin istatistiksel olarak anlamsız olduğu görülmüştür. Grup ve zaman değişkenlerinin ortak etkisinin ise anlamlı olduğu saptanmıştır (Wilk’s $\lambda=.856, F(1,58)=9.785, p<.01, \eta^{2}=$ .14). İkili karşılaştırmalarda ön testten $($ Ort. $=15.90, S S=5.46)$ son teste $($ Ort. $=14.40$, $S S=4.52$ ) eğitim grubunun puanları anlamlı bir şekilde azalırken, karşılaştırma grubunun puanları ön testten (Ort. $=14.07, S S=4.98)$ son teste $($ Ort. $=15.27, S S=5.25)$ marjinal olarak anlamlı bir biçimde artmaktadır. Eğitimin sonunda eğitim grubunun ön 
testten son teste öfkelerini daha az dişa yöneltirken, karşılaştırma grubunun daha fazla dışa yönlendirmesi H11'in desteklendiğini göstermektedir.

\section{TARTIŞMA}

$\mathrm{Bu}$ araştırmanın amacı, ülkemizde bir açık CİK'te kalan yetişkinlere uygulanan Topluma Yeniden Uyum Programı'nın etkililiğinin değerlendirilmesidir. Uygulamaların ardından yapılan değerlendirmelerde programın iletişim ve öfke konularında görece etkili olduğu görülmüştür. Alan yazında BDY'ye dayanan programların öfke ve kişilerarası problem çözme konusunda etkili olduğu vurgulanmaktadır (Landenberger ve Lipsey, 2005).

Yapılan araştırmada $H 1$ - H5 hipotezlerinin doğrulandığ1, programın iletişim becerileri ölçeğinin alt ölçekleri olan temel beceriler ve kendini ifade etme, iletişime özen gösterme, ilişki kurmaya isteklilik, etkin dinleme ve sözel olmayan iletişim, iletişim ilkelerine uyma puanları üzerinde etkili olduğu saptanmıştır. Çalışmada iletişim konusundaki birinci ve dördüncü hipotezlerin doğrulandığı bir başka deyişle temel beceriler ve kendini ifade etme ile etkin dinleme ve sözel olmayan iletişim puanlarının eğitim grubundaki katılımcılarda ön testten son teste arttı̆̆ saptanmıştır. Ayrıca iletişime özen gösterme, ilişki kurmaya isteklilik ve iletişim ilkelerine uyma puanları karşılaştırma grubunda anlamlı bir biçimde azalırken eğitim grubundaki katılımcıların puanlarının korunduğu görülmüştür. $H 1, H 3$ ve $H 5$ hipotezlerinde ifade edildiği gibi eğitim uygulamalarının eğitim grubunun puanlarında bir artış sağlamamasına rağmen karşılaştırma grubunda gözlenen düşüşün eğitim grubunda gözlenmemesi eğitim programının bu konularda da etkili olduğunu düşündürmektedir. Schippers ve arkadaşları (2001) bu çalışmanın sonuçlarına benzer biçimde hükümlülerin eğitim programının ardından sosyal becerilerinin arttığını belirtmişlerdir. Hayward ve arkadaşları da (2008) toplumsal sorun çözme eğitiminin etkili olduğunu belirtmektedirler. Ülkemizde ergen hükümlülerle yapılan bir müdahale çalışmasında da eğitimden sonra katılımcıların iletişim becerilerinin arttığı bulunmuştur (Kızıltepe ve ark., 2021). Hükümlülerin CIKK'teki koşullarda iletişimin temel becerilerinden ziyade daha karmaşık olan önyargısız dinleme, yakın ilgi duyma ve iletişimi başlatabilme gibi konularda zorlandıkları düşünülmektedir. Ayrıca eğitim sonrasında salıverilme zamanlarının giderek yaklaşması da yeni ilişkiler kurmaya ve ilişkilerini derinleştirmeye anlamlı olarak daha az istekli olmalarına neden olmuş olabilir. Bu yaşantılara karşın, Topluma Yeniden Uyum Programı'nın eğitim grubundaki 
katılımcıların iletişim becerilerinin korunmasına katkı sağlaması bu alanda etkili olduğunu düşündürmektedir. Program, eğitim alan hükümlülerin temel beceriler ve kendini ifade etme ve etkin dinleme ve sözel olmayan iletişim becerilerini arttırmakla birlikte, iletişime özen gösterme, ilişki kurmaya isteklilik ve iletişim ilkelerine uyma konularında karşılaştırma gruplarında görülen düşüşü ödünlediğinden sonraki yapılacak çalışmalarda bu üç alanda da iletişim artışını sağlamak hedefiyle programın iyileştirilmesi önerilmektedir.

Yapılan analizlerde $H 6$ ve $H 7$ 'nin doğrulanmadığı ve hem karşılaştırma hem de eğitim grubunda stresin arttı̆̆ gözlenmiştir. Bunun olası açıklamalarından biri, CíK'lerin fiziksel-sosyal kısıtlılıklar ve kontrol dışı pek çok faktör içermesi nedeniyle stres yaşanan ortamlar olmalarıdır (Nurse, Woodcock ve Ormsby, 2003). Kurumda stres yaratan faktörlerin incelenmesi önemlidir. CİK'lerde hükümlülerin yaşadığı stresin azaltılabilmesi için stresle başa çıkma becerilerini öğreten programların daha uzun süreli uygulanmasının, programların stresin azaltılması konusundaki etkililiğine katkı sağlayacağı düşünülmektedir. Bu çalışmadaki programda stres konularına ayrılan zaman dört saattir. Sonraki çalışmalarda daha fazla etkinlik, alıştırma ve ödev gibi uygulamaların programa eklenmesi ve sürenin arttırılması yararlı olabilir. İkinci olarak, hükümlülerin araştırmanın uygulandığı tarihlerde yeni bir yargı paketinin çıkacağı ve bu doğrultuda CİK'lerden salıverilmelerin olacağı haberini almış oldukları gözlenmiştir. Bu konuda yaşanan belirsizlikler katılımcıların stresini arttırmış olabilir. Sonuç olarak, BDY temelli Topluma Yeniden Uyum Programı'nın stres eğitimi modülünün yeniden düzenlenmesi ve geliştirilmesi gerekli görülmektedir.

Bu çalışmada eğitim grubundaki katılımcıların sürekli öfke puanlarının değişmediği dolayısıyla $H 8^{\prime}$ 'in desteklenmediği saptanmıştır. Bu bulgu katılımcıların öfke duygusunu yaşama sıklığının azalmadığına işaret etmektedir. Alan yazında da bu çalışmanın sonuçlarına benzer şekilde müdahale programının ardından öfke duygusunu yaşama sıklığının değişmediğini bildiren çalışmalar bulunmaktadır (Heseltine ve ark., 2010; Watt ve Howels, 1999). Bu bulgunun birkaç olası nedeni olabilir. İlk olarak sürekli öfke duygusu yaşamanın bir yatkınlık ve örüntü olduğu bilinmektedir (Kassinove, Roth, Owens ve Fuller, 2002; Spielberger, Reheiser ve Sydeman, 1995). Bu nedenle bu yatkınlığı değiştirmek için daha uzun süreli ve yoğunlaştırılmış programlara ihtiyaç olabilir. Dahası CİK koşulları düşünüldüğünde, kısıtlılık ve belirsizlikler öfke duygusunun sıklıkla yaşanmasına sebep oluyor olabilir. Ayrıca bu çalışmada $H 9$, $H 10$ ve $H 11$ 'in des- 
teklendiği ve eğitim grubundaki katılımcıların karşılaştırma grubuna göre öfkeyi daha az içte tutmaya, daha az dişa vurmaya ve daha fazla kontrol etmeye başladıkları görülmüştür. Alan yazında müdahale programlarının öfkeyi ifade etme becerileri üzerine etkisini inceleyen çalışmaların sonuçları çelişkilidir. Bazı araştırmalar müdahale programlarının öfkenin ifadesi üzerinde anlamlı bir etkiye sahip olmadığını belirtirken (Heseltine ve ark., 2010; Howells ve ark., 2005), diğer çalışmalar müdahale programlarının etkili olduğunu göstermiştir (Ireland, 2004; Schippers ve ark., 2001). Bu çalışmanın bulguları müdahale programlarının öfkenin sağlıklı bir biçimde ifade edilmesi üzerinde etkili olduğunu gösteren çalışmaları destekler niteliktedir. Özetle, BDY temelli Topluma Yeniden Uyum Programı'nın öfkeyi ifade etme konusunda başarılı olduğu düşünülürken, sürekli öfkeyi azaltmak için programın içeriğindeki uygulama ve ödevlerin arttırılmasının yanı sıra bu modüle ayrılan sürenin de arttırılması önerilmektedir.

Yetişkin hükümlüler için bir eğitim programı hazırlanmasını ve bu programın etkililiğinin incelenmesini kapsayan bu çalışmanın bazı güçlü yanları bulunmaktadır. Yetişkin hükümlülerin topluma uyumunu sağlamayı amaçlayan programın etkililiğinin gösterilmesinin alan yazına katkı sağlayacağı düşünülmektedir. Ayrıca bu çalışmada etik ilkeler gözetilerek karşılaştırma grubundaki katılımcılara son test ölçümlerinden hemen sonra eğitim programı uygulanmıştır.

Alana katkılarının yanı sıra çalışmanın birtakım sınırlılıkları da bulunmaktadır. Program açık CİK'te bulunan, salıverilmesine bir yıl kalan hükümlü olan kişilere uygulanmıştır ve bulguların genellenebilirliği bu örneklem özellikleri ile sınırlıdır. Araştırmanın örneklemi şiddet ile ilişkili bulunan yaralama, kasten öldürme gibi davranışlar nedeniyle hüküm giyen katılımcılardan oluşmaktadır, ancak katılımcıların sergiledikleri suç eyleminin detayları hakkında daha fazla bilgi bulunmamaktadır. Suç eyleminin özellikleri (örn., kadına yönelik şiddet) dikkate alınarak, programın etkililiğinin yeniden incelenmesi önerilmektedir. Ayrıca kapalı CİK'lerde bulunan hükümlüler, kadın hükümlüler vb. gibi diğger gruplarla da programın etkililiğinin değerlendirilmesi önerilmektedir. Programın uygulanmasının ardından alınan son test ölçümleri programın birçok açıdan etkili olduğunu göstermesine rağmen, uzun dönem etkilerine ilişkin bir bilgi bulunmamaktadır. Gelecekte CİK'lerde yapılacak olan araştırmalarda kurumdan salıverilmeden sonra da izlem ölçümlerinin alınması önemlidir.

Sonuç olarak, ceza infaz kurumlarında bulunan hükümlülerin tekrar suç işlemesini önlemek ve toplumsal yaşama uyumlarını kolaylaştırmak için iyileştirme faaliyetleri ol- 
dukça önemlidir. Bu araştırmada uygulanan programın yetişkin hükümlülerin öfke denetimi ve iletişim becerilerini arttırarak salıverilmelerinin ardından toplumsal yaşama uyumlarını desteklemesi beklenmektedir.

Açık ceza infaz kurumlarında kapalı ceza infaz kurumlarına oranla olanakların daha çok olduğu bilinmektedir. Bu sebeple salıverilmesine az kalan hükümlülerin bulunduğu açık ceza infaz kurumlarında, bireylerin toplumsal yaşama kazandırılması için iyileştirme faaliyetlerinin arttırılması oldukça önemlidir.

Etik Komite Onayı: Araştırma için Ege Üniversitesi Bilimsel Araştırma ve Yayın Etiği Kurulu'ndan 28.03.2019 tarih ve 04/17 karar sayılı (Protokol Numarası: 211) etik kurul onayı alınmıştır.

Hakem Değerlendirmesi: Dış bağımsız.

Yazar Katkıları: Çalışma Konsepti/Tasarım- A.M., T.Y.I.; Veri Toplama- A.M.; Veri Analizi/Yorumlama- R.K., T.Y.I.; Yazı Taslağı- A.M., R.K., T.Y.I.; İçeriğin Eleştirel İncelemesi- T.Y.I.; Son Onay ve Sorumluluk- A.M., R.K., T.Y.I.

Çıkar Çatışması: Yazarlar çıkar çatışması bildirmemiştir.

Finansal Destek: Yazarlar bu çalışma için finansal destek almadığını beyan etmiştir.

Ethics Committee Approval: Ethics committee approval was obtained for the research from Ege University Scientific Research and Publication Ethics Committee, dated 28.03.2019 and decision numbered 04/17 (Protocol Number: 211). Peer-review: Externally peer-reviewed.

Author Contributions: Conception/Design of Study- A.M., T.Y.I.; Data Acquisition- A.M.; Data Analysis/InterpretationR.K., T.Y.I.; Drafting Manuscript- A.M., R.K., T.Y.I.; Critical Revision of Manuscript- T.Y.I.; Final Approval and Accountability- A.M., R.K., T.Y.I.

Conflict of Interest: The authors have no conflict of interest to declare.

Grant Support: The authors declared that this study has received no financial support.

\section{Kaynakça/References}

Adalet Bakanlığı (2017). 2016 yılı bakanlık faaliyet raporu. Erişim adresi: http://www.sp.gov.tr/upload/ xSPRapor/files/JZcki+Adalet_Bakanligi_Faaliyet_Raporu2016.pdf

Aksel, E. Ş. (2012). Çocuk suçluluğuna genel bakış. Ş. Aksel ve T. Yılmaz-Irmak (Ed.), Gelişim psikolojisi bakış açısıyla çocuk suçluluğu içinde (s. 1-21). Ege Üniversitesi Yayınevi

Alexander, R. (2000). Counseling, treatment and intervention methods with juvenile and adult offenders. Brooks/Cole.

Allen, L.C., Mackenzie, D. L. ve Hickman L. J. (2001). The effectiveness of cognitive behavioral treatment for adult offenders: A methodological, quality-based review. International Journal Offender Therapy And Comparative Criminology, 45(4), 498-514. https://doi.org/10.1177\%2F0306624X01454009

Antonowicz, D. H. ve Ross, R. R (2005). Social problem-solving deficits in offenders. M. McMurran ve J. McGuire (Ed.), Social problem solving and offending: Evidence, evaluation and evolution (Vol. 22) içinde (s. 91-102). West Sussex: John Wiley \& Sons.

Biggam, F. H. ve Power, K. G. (1999). A comparison of the problem solving abilities and psychological distress of suicidal, bullied, and protected prisoners. Criminal Justice and Behavior, 26, 196-216. https://doi.org/10.1177\%2F0093854899026002003

Bilici, R., Ögel, K., Bahadır, G. G., Maçkan, A., Orhan, N. ve Tuna, O. (2018). Treatment outcomes of drug users in probation period: Three months follow-up. Psychiatry and Clinical Psychopharmacology, 28(2), 149-155. https://doi.org/10.1080/24750573.2017.1391156 
Bourke, M. L. ve Van Hasselt, V. B. (2001). Social problem-solving skills training for incarcerated offenders: A treatment manual. Behavior Modification, 25(2), 163-188. https://doi. org $/ 10.1177 \% 2 \mathrm{~F} 0145445501252001$

Canter, D. (2011). Suç psikolojisi (A. Dönmez, I. Çoklar Başer ve M. Güler, Çev.). Ankara: İmge Kitabevi

Çiftçi, G. E. ve Tüfekçi, İ. (2017). Çalışanlarda öfke ifade tarzının örgütsel iletişime etkisi: Sungurlu Belediyesi örneği. Sosyal Bilimler Dergisi, 15, 399-412.

Cohen, S., Kamarck, T. ve Mermelstein, R. (1983). A global measure of perceived stress. Journal of Health and Social Behavior, 24, 385-396.

Çaynak, S. ve Kutlu, Y. (2016). Bir grup tutuklu ve hükümlünün ruhsal belirtileri, intihar olasılı̆̆ ve başa çıkma yolları. Anadolu Psikiyatri Dergisi, 17(2), 93-98.

Demir, G. (2015). Ceza infaz kurumu kütüphaneleri: Dünyada ve Türkiye'de durum. İstanbul: Hiperlink Yayınları.

Diong, S.-M., Bishop, G. D., Enkelmann, H. C., Tong, E. M. W., Why, Y. P., Ang, J. C.H. ve Khader, M. (2005). Anger, stress, coping, social support and health: Modelling the relationships. Psychology \& Health, 20(4), 467-495. https://doi.org/10.1080/0887044040512331333960

Duran, Ö. ve Eldeleklioğlu, J. (2005). Öfke kontrol programının 15 ve 18 yaş arası ergenler üzerindeki etkililiğinin araştırılması. Gazi Üniversitesi Gazi Ĕgitim Fakültesi Dergisi, 25(3), 267-280.

Eher, R., Rettenberger, M. ve Turner, D. (2019). The prevalence of mental disorders in incarcerated contact sexual offenders. Acta Psychiatrica Scandinavica, 139(6), 572-581. https://doi.org/10.1111/ acps. 13024

Eskin, M., Harlak H., Demirkıran F. ve Dereboy Ç. (2013). Algılanan stres ölçeğinin Türkçeye uyarlanması: Güvenirlik ve geçerlik analizi. New Symposium Journal, 51(3), 132-140.

Fazel, S. ve Danesh, J. (2002). Serious mental disorder in 23000 prisoners: A systematic review of 62 surveys. The Lancet, 359(9306), 545-550. https://doi.org/10.1016/S0140-6736(02)07740-1

Fazel, S., Hayes, A. J., Bartellas, K., Clerici, M. ve Trestman, R. (2016). Mental health of prisoners: Prevalence, adverse outcomes, and interventions. The Lancet Psychiatry, 3(9), 871-881. https://doi. org/10.1016/S2215-0366(16)30142-0

Hayes, L. M. (1989). National study of jail suicides: Seven years later. Psychiatric Quarterly, 60(1), 7-29. https://doi.org/10.1007/BF01064362

Hayward, J., McMurran, M. ve Sellen, J. (2008). Social problem solving in vulnerable adult prisoners: Profile and intervention. The Journal of Forensic Psychiatry \& Psychology, 19(2), 243-248. https:// doi.org/10.1080/14789940701752193

Henwood, K. S., Chou, S. ve Browne, K. D. (2015). A systematic review and meta-analysis on the effectiveness of CBT informed anger management. Aggression and Violent Behavior, 25, 280-292. https://doi.org/10.1016/j.avb.2015.09.011

Heseltine, K., Howells, K. ve Day, A. (2010). Brief anger interventions with offenders may be ineffective: A replication and extension. Behaviour Research and Therapy, 48(3), 246-250. https:// doi.org/10.1016/j.brat.2009.10.005

Hollin, C. R. (1999). Treatment programs for offenders: Meta-analysis, "what works," and beyond. International Journal of Law and Psychiatry, 22(3-4), 361-372. https://psycnet.apa.org/doi/10.1016/ S0160-2527(99)00015-1

Howells, K., Day, A., Williamson, P., Bubner, S., Jauncey, S., Parker, A. ve Heseltine, K. (2005). Brief anger management programs with offenders: Outcomes and predictors of change. The Journal of Forensic Psychiatry \& Psychology, 16(2), 296-311. https://doi.org/10.1080/14789940500096099

Ireland, J. L. (2004). Anger management therapy with young male offenders: An evaluation of treatment outcome. Aggressive Behavior: Official Journal of the International Society for Research on Aggression, 30(2), 174-185. https://doi.org/10.1002/ab.20014 
İskit, Y. (2019). Beş basamakl öfke kontrol eğitiminin yetişkinlerdeki öfke düzeyine etkisi (Yayımlanmamış Yüksek Lisans Tezi). İbni Haldun Üniversitesi Lisansüstü Eğitim Enstitüsü

Kassinove, H., Roth, D., Owens, S. G. ve Fuller, J. R. (2002). Effects of trait anger and anger expression style on competitive attack responses in a wartime prisoner's dilemma game. Aggressive Behavior: Official Journal of the International Society for Research on Aggression, 28(2), 117-125. https:// doi.org/10.1002/ab.90013

Kızıltepe, R., Gümüşten, D., Sağel-Çetiner, E., Ebeoğlu, M., Yılmaz-Irmak, T. ve Aksel, Ş. (2021). The effect of a new intervention program for male juvenile offenders on socio-emotional and cognitive outcomes in Turkey. (Yayınlanmak üzere gönderilen yazı).

Kifer, M., Hemmens, C. ve Stohr, M. K. (2003). The goals of corrections: Perspectives from the line. Criminal Justice Review, 28(1), 47-69. https://doi.org/10.1177\%2F073401680302800104

Korkut-Owen, F. ve Bugay, A. (2014). İletişim Becerileri Ölçeği'nin geliştirilmesi: Geçerlik ve güvenirlik çalışması. Mersin Üniversitesi Eğitim Fakültesi Dergisi, 10(2), 51-64.

Korkut-Owen, F. K. ve Demirbaş Çelik, N. D. (2018). Yetişkinlerin cinsiyetlerine, yaşlarına ve kişilik özelliklerine göre iletişim becerilerinin incelenmesi. Journal of Human Sciences, 15(4), 23052321. https://doi.org/10.14687/jhs.v15i4.5394

Landenberger, N. A. ve Lipsey, M. W. (2005). The positive effects of cognitive-behavioral programs for offenders: A meta-analysis of factors associated with effective treatment. Journal of Experimental Criminology, 1(4), 451-476. https://doi.org/10.1007/s11292-005-3541-7

Lipsey, M. W., Chapman, G. L. ve Landenberger, N. A. (2001). Cognitive-behavioral programs for offenders. The Annuals of the American Academy of Political and Social Science, 578(1), 144-157. https://doi.org/10.1177\%2F000271620157800109

Lipsey, M. W., Landenberger, N. A. ve Wilson, S. J. (2007). Effects of cognitive-behavioral programs for criminal offenders. Campbell Systematic Reviews, 3(1), 1-27. https://doi.org/10.4073/csr.2007.6

Mpofu, E., Athanasou, J. A., Rafe, C. ve Belshaw, S. H. (2018). Cognitive-behavioral therapy efficacy for reducing recidivism rates of moderate-and high-risk sexual offenders: A scoping systematic literature review. International Journal of Offender Therapy and Comparative Criminology, 62(1), 170-186. https://doi.org/10.1177\%2F0306624X16644501

Novaco, R. W., Ramm, M. ve Black, L. (2004). Anger treatment with offenders. C. R. Hollin (Ed.) The essential handbook of offender assessment and treatment içinde (s. 129-144). New York: Wiley.

Nurse, J., Woodcock, P. ve Ormsby, J. (2003). Influence of environmental factors on mental health within prisons: Focus group study. BMJ, 327(7413), 480. https://doi.org/10.1136/bmj.327.7413.480

Ögel, K., Bilici, R., Bahadır, G. G., Maçkan, A., Orhan, N. ve Tuna, O. (2016). Denetimli serbestlikte, sigara, alkol madde bağımlılı̆̆ tedavi programı (SAMBA) uygulamasının etkinliği. Anadolu Psikiyatri Dergisi, 17(4), 270-277. http://dx.doi.org/10.5455/apd.200521

Özbay, Ö. Y. (2008). Öfke kontrolü eğitim programının etkililiğinin tutuklu bir grup ergen örnekleminde incelenmesi (Yayımlanmamış Doktora Tezi). Ankara Üniversitesi Sağlık Bilimleri Enstitüsü

Özdemir, E. (2009). Muş E Tipi Kapalı Ceza İnfaz Kurumu'nda kasten adam öldürmek suçundan gelen hükümlü erkeklerde öfke ve öfke ifade tarzları ile saldirganlık ilişkisinin incelenmesi. (Yayımlanmamış Yüksek Lisans Tezi). Çukurova Üniversitesi Sağlık Bilimleri Enstitüsü.

Özden, S. Y. (2015). Adli psikiyatri (2. baskı). Ankara: Nobel Akademik Yayıncılık

Özer, A. K. (1994). Sürekli öfke ve öfke ifade tarzı ölçekleri ön çalışması. Türk Psikoloji Dergisi, 9(31), 26-45.

Pliszka, S. R., Sherman, J. O., Barrow, M. V. ve Irick, S. (2000). Affective disorder in juvenile offenders: A preliminary study. American Journal of Psychiatry, 157(1), 130-132. https://doi.org/10.1176/ ajp.157.1.130 
Polaschek, D. L. ve Collie, R. M. (2004). Rehabilitating serious violent adult offenders: An empirical and theoretical stocktake. Psychology, Crime \& Law, 10(3), 321-334. https://doi.org/10.1080/106 83160410001662807

Polat, O. (2004). Kriminoloji ve kriminalistik üzerine notlar. Ankara: Seçkin Yayınları

Porsuk, S. (2017). Hükümlülerin topluma kazandırllmasında denetimli serbestliğin rolü: Malatya ili örneği. (Yayımlanmamış Yüksek Lisans Tezi). Fırat Üniversitesi Sosyal Bilimler Enstitüsü

Redondo, S., Sanchez-Meca, J. ve Garrido, V. (1999). The influence of treatment programmes on the recidivism of juvenile and adult offenders: An European meta-analytic review. Psychology, Crime and Law, 5(3), 251-278. https://doi.org/10.1080/10683169908401769

Rogers, K. (2011). Tutukevinde psikoloji. D. Canter (Ed.), Suç psikolojisi içinde (s. 409-446). Ankara: İmge Kitabevi

Schippers, G. M., Märker, N. ve De Fuentes-Merillas, L. (2001). Social skills training, prosocial behavior, and aggressiveness in adult incarcerated offenders. International Journal of Offender Therapy and Comparative Criminology, 45(2), 244-251. https://doi.org/10.1177\%2F0306624X01452009

Spielberger, C. D., Jacobs, G., Russell, S. ve Crane, R. (1983). Assessment of anger: The state-trait anger scale. J. N. Butcher ve C. D. Spielberger (Ed.), Advances in personality assessment içinde (s. 161-189). Erlbaum.

Spielberger, C. D., Reheiser, E. C. ve Sydeman, S. J. (1995). Measuring the experience, expression, and control of anger. H. Kassinove (Ed.), Anger disorders: Definitions, diagnosis, and treatment içinde (s. 49-76). Washington, DC: Taylor \& Francis

Şekerci, Y. G., Terzi, H., Kitiş, Y. ve Okuyan, C. B. (2017). Sekizinci sınıf öğrencilerine bilişsel davranışçı yaklaşıma göre uygulanan öfke kontrol programının etkinliği. Dokuz Eylül Üniversitesi Hemşirelik Fakültesi Elektronik Dergisi, 10(4), 201-207.

Tekinsav Sütcü, S., Aydın, A. ve Sorias, O. (2010). Ergenlerde öfke ve saldırganlığı azaltmak için bilişsel davranışçı bir grup terapisi programının etkililiği. Türk Psikoloji Dergisi, 25(66), 57-67.

Ünlü-Sağdıç, E. (2019). Problem çözme eğitimi grup yaşantısının kadın mahkumların sosyal problem çözme becerilerine etkisinin incelenmesi (Yayımlanmamış Yüksek Lisans Tezi). Çağ Üniversitesi Sosyal Bilimler Enstitüsü.

Watt, B. D. ve Howells, K. (1999). Skills training for aggression control: Evaluation of an anger management programme for violent offenders. Legal and Criminological Psychology, 4(2), 285300. https://doi.org/10.1348/135532599167914

Wilson, D. B., Gallagher, C. A. ve MacKenzie, D. L. (2000). A meta-analysis of corrections-based education, vocation, and work programs for adult offenders. Journal of Research in Crime and Delinquency, 37(4), 347-368. https://doi.org/10.1177\%2F0022427800037004001

Yakışır, B. (2006). Türkiye'de tutuklu ve hükümlülerin yeniden sosyalleştirilmesi (Yayımlanmamış Yüksek Lisans Tezi). İstanbul Bilgi Üniversitesi Sosyal Bilimler Enstitüsü. 